\title{
Regrettable Pursuits: Dual Narrative Voice in the Joy Luck Club
}

\author{
Yanan He \\ Neijiang Normal University, Neijiang, 641112, China
}

\section{Key Words: the Joy Luck Club; personal narrative voice; dual narrative voice}

Abstract. In the past few decades, identity was the popular topic in the literary criticism when researches went for The Joy Luck Club, including the author's cultural identity, gender identity, and ethnic identity. There is no denying that culture must be the important topic with the globalization of the world. However, my paper intends to deal with this seemingly old topic from the perspective of feminist narratology in order to prove how Amy Tan, by adopting unique dual narrative voice in the novel, attempts to make Chinese American women hold an authority of their own voice.

The Joy Luck Club is one of Amy Tan's most successful novels. The literary reputation of Amy Tan is well established by this novel which has caught attention and aroused sensation inside and outside America. With its unique narrative techniques, the novel has aroused great interest among scholars. In order to lead readers into the inner world of the characters', Tan has adopted personal narrative voice to give each woman a chance to tell her own story. As the main character in the novel, June is given the privilege to tell her mother's story as well as hers. Dual narrative voice can be heard by the readers clearly, which, at the same time, makes the narration convincing. Hence, the authority of Chinese American women's narrative voice can be achieved.

\section{Personal Narrative Voice}

When mentioning personal voice, Susan Lanser refers to narrators who are self-consciously telling their own histories. Genette calls it "autodiegetic," in which the "I" who "tells the story is also the story's protagonist” (Lanser, 1992: 16-17).

The two terms "homodiegetic" and "autodiegetic" are mentioned by Gerard Genette in his representative work of structualist narratology--- Narrative Discourse. The term "homodiegetic" refers to the narrator who is also a character in the story he tells. The character can be the hero or only a secondary role in the story. The term "autodiegetic" refers to the first variety. However, Susan does not intend personal voice to designate all "homediegetic" or "first-person" narratives, but only those Genette calls "autodiegetic", in which the narrator "I" is also the hero in the story he tells.

Personal voice is different from authorial voice in that in autodiegetic narration, the autodiegetic "I" is structurally superior to other voices in a novel. However, it does not enjoy the superhuman privileges that are enjoyed by authorial voice, and its status is dependent on a reader's response not only to the narrator's acts but to the character's actions. So authorial narrators claim to have powers of knowledge and judgment, while personal narrators claim only the validity of one person's interpret his or her experiences. That's why novels written in the personal voice are always treated as autobiography, for fear of which, women writers in patriarchal societies may deliberately avoid person voice. Women's novels are easily stamped as "self-expression", the product of "intuition" rather than of art (Lanser, 1992: 20).

\section{The Dual Narrative Voice in June’s Personal Narrative Voice}

Even though the other three daughters and mothers tell their own stories in personal narrative voice, June's personal narrative voice is different because the voice of daughter and mother, namely, the dual narrative voice, can be heard clearly by the readers.

When "I" refers to the unique existence on a specific space and time, the "self" is likely to be in a contradictory state because "I" might observe "I" from the point of view belonging to others: the present "I" observe the "I" in the past, the flesh "I" observe the spiritual "I", the ideal "I" observe the "I" in the reality. The conflicts might arise between the two "I"s because of the inner 
contradictions. In the novel, June and her mother, both of them, have experienced the conflicts between the two worlds: traditional Chinese culture and modern American culture, the past and the today. They are constantly struggling and getting lost in the two worlds. They think they have two faces, living in the corner of the world where they can not see and hear anyone and they can not be seen and heard either. Nobody will know their existence. The inner contradictions and conflicts between the two "I"s bring about the dialogue between the two "I"s. Amy Tan, by adopting the personal narrative voice, provided a perfect space for the dialogue for both "self". In the first section "Feathers from a Thousand Li Away", June recalls, in her mother's voice, her mother's experiences in Old China--- separation and union, happiness and sorrows, which help the readers to make a conscious attention to the sufferings of Chinese women. In the narration of the mother's personal story, the first person narration is adopted. So the narrator "I" and the character "I" make the dual voice which represents two speeches, two view points.

The opening of the story places June in the uneasy situation of having to take her recently deceased mother's place at the Joy Luck Club meeting. Feeling out of place, she imagines that the three Joy Luck aunties "must wonder now how someone like me can take my mother's place" (Tan, 1989: 27). When put in the precarious position of having to go to China to fulfill her dead mother's lifelong quest--- of being reunited with her long lost twin daughters and tell them their mother's life, June asks herself “How can I describe to them in Chinese about our mother's life?” (Tan, 1989: 287) What's more, the hard time June suffers to think of the cause of her mother's death can also reflects her failure in understanding her mother. She turns to people close to her mother, and finds various answers:

... My father thinks she was killed by her own thoughts.

"She had a new idea inside her head," said my father, "But before it could come out of her mouth, the thought grew too big and burst..." The doctor said she died of a cerebral aneurysm. And her friends at the Joy Luck Club said she died just like a rabbit. (Tan, 1989: 5)

However, June does not feel comfortable to accept any of the answers. She whispered, “They'll think I'm responsible, that she died because I didn’t appreciate her” (Tan, 1989: 311).

All of the above is presented by June's personal narrative voice focalizing on her mother's death. June gives the doctor's and the friends' opinions in indirect speech. When reporting her father's thought, June goes beyond her limit as a first-person narrator, as she can only go as far as her own consciousness and whatever she can observe from others. It is noticeable that June does not give her opinion about her mother's death in the beginning. By using indirect thought by her father, indirect speeches by her mother's friends and the doctor, June keeps the narration under her control with her voice alongside theirs. As the word "said" suggests, the aunties and the doctor provide the objective aspects of the death. However, the word "think" and "whisper" suggest the subjective interpretations of her father's and June's. Obviously, June is eager to find out the truth of her mother's death from other people's opinion; however, June is not convinced. She has to eventually voice her own opinion. She "whispers" in a timid way, which projects an assumed thought from the half-sisters who she has never met and never communicated with. Even though the assumption is conveyed in June's personal narrative voice, it reveals June's troubled inner world. The doctor's opinion is most objective while the father's judgment is rather subjective when he says that Suyuan is "killed" by her own "thoughts". This gives suspense to what "the thoughts" are that killed Suyuan. All this turn out to be the threads leading June into her mother's inner world.

It is difficult for June to understand her mother without knowing what joy and luck meant. The meaning of joy and luck changes and becomes clearer as June digs deeper into Suyuan's life, which becomes a very important thread for her to understand her mother, her mother's expectation of her, and eventually her own identity of being Chinese.

I never thought my other's Kweilin story was anything but a Chinese fairy tale. The ending always changed.

And then one evening, ... and then she told me a completely different ending to the story.

In those days, I imagined Joy Luck was a shameful Chinese custom. (Tan, 1989: 25-28)

The sentences above are narrated in June's personal voice. From such words as "never", 
"always", "completely", and "shameful”, it is noticeable that June develops unfavorable impression of the "joy luck". Especially when these negative words go along with two adjectives "Chinese", it is safe to say that June is in a distance from her Chinese heritage.

The Kweilin version is given by Suyuan in her personal voice. June gives the stage to Suyuan when Joy Luck story is told. Suyuan's personal voice renders June a listener. The personal voice adopted by Suyuan makes the story original and authoritative, which brings about an unusually long speech, an indication that her voice still rings in June's ears. The personal voice allows Suyuan to speak her mind, and brings out the significance of the Joy Luck Club.

To Suyuan, the story is set in Kweilin. She imagines Kweilin as a beautiful place that everyone dreams about. But very soon, the war makes "a city of leftovers mixed together". Very quickly Kweilin lost its beauty for Suyuan. What's more, the city gave her pain lasting throughout most of her life.

Even though Suyuan shares fear and misery with other people, the strong will makes them make a conscious decision for a purpose. They decide to choose their own happiness by holding parties and playing Mahjong. The hope in winning the game becomes their only joy. That's why they call the parties Joy Luck. By adopting personal narrative voice, Suyuan keeps in control of her narration. While there is other people's voice in the narration which convey the argument and even criticism, Suyuan, the narrator's voice is also articulated and prevails in the narration.

When telling her mother's story back in China, June uses the mother's tongue while it is from the daughter's point of view. The guiding spirit of this myth is Suyuan. The story is unmistably the daughter's version of the family romance in which family members are separated, lost, and reunited.

If Kweilin version of the Joy Luck Club is for Suyuan and her friends to say no to fear and misery, the San Francisco version serves the same purpose. This version is narrated in June's personal voice when she reveals “America was where my mother's hopes lay.” (Tan, 1989: 141).

My mother could sense that the women of these families also had unspeakable tragedies they had left behind in China and hopes they couldn't begin to express in their fragile English. Or at least, my mother recognized the numbness in these women's faces. And she saw how quickly their eyes moved when she told them her idea for the Joy Luck Club. (Tan, 1989: 6-7)

The words "hopes”, "sense", "recognized", and "saw" can reveal the mental process of Suyuan. In this narration, June uses Suyuan as the focalizer while the voice is still there. By using her mother's senses, June slips into her mother's mind and give the account from her mother's emotive point of view as a narrator. This becomes a symbol to show June begins to know her mother's thought and inner world, as well as a symbol of her taking in the Joy Luck tradition. Even while protesting that she doesn't know enough to tell her mother's story, June nevertheless proves correct her aunties' insistence, "Your mother is in your bones! ... her mind ... has become your mind" (Tan, 1989: 40).

\section{Conclusion}

As the influential writer of Chinese American literature, Tan is adept at portraying motherldaughter plot: the intense conflict and contradiction between mothers and daughters in immigrant families. Despite Tan's explicit embrace of the daughter's perspective, The Joy Luck Club is remarkable for foregrounding the voice of the mother as well as the daughter. The two voices enhance and complement each other, pushing the plot to the climax. By combining both voices of the mother and the daughter, Tan mixed concealed content and the natural narrative attitude and constructed a rational narrative identity for the images and yield a multiple female consciousness. So it is safe to say that using the dual narrative voice in The Joy Luck Club, Tan, with the identity as a Chinese American female writer, has constructed narrative authority.

\section{Acknowledgments}

This paper is the general research project of Neijiang Normal University: the narrative voice 
research of the works of American minority women writers (project number: 13SB07).

\section{References}

[1]Bow, Leslie. “Cultural Conflict/Feminist Resolution in Amy Tan's The Joy Luck Club” in New Visions in Asian American Studies: Diversity, Community, Power, edited by Franklin Ng, Judy Yung, Stephen S. Fugita, Elaine H. Kim. Pullman: Washington State University Press, 1994.

[2]Dai, Fan. Speech and Thought Presentation in The Joy Luck Club. Guangzhou: Zhongshan University Press, 2005.

[3]Genette, G. Narrative Discourse. Trans: Jane E. Lewin. Ithaca: Cornell University, 1980.

[4]Lanser, Susan. The Narrative Act: Point of View in Prose Fiction. Princeton: Princeton University Press, 1981.

[5]Lanser, Susan. “Toward a Feminist Narratolog” (1986) in Feminisms: An Anthology of Literary Theory and Criticism, edited by Robyn R. Warhol and Diane Price Herndl. New Brunswick: Rutgers University Press, 1991

[6]Lanser, Susan. Fictions of Authority: Women Writers and Narrative Voice. New York: Cornell University Press, 1992.

[7]Tan, Amy. The Joy Luck Club. New York: Penguin Group, 1989. 